\title{
GERMINATION OF THREE LEGUMES: ONOBRYCHIS SUBNITENSE BORNM., ONOBRYCHIS SCROBICULATA BOISS., AND VICIA VARIABILIS GROSSH. AT DIFFERENT TEMPERATURES
}

\author{
GORGIN KARAJI, M. ${ }^{1 *}-$ VAHABI, M. R. ${ }^{1 * *}-$ SIOSEMARDEH, A. ${ }^{2}$ - HOSSEINPANAHI, F. $^{2}-$ \\ ESHGHIZADEH, $\mathrm{H}^{3}{ }^{3}$ - BASSIRI ESFAHANI, M. ${ }^{1}$ \\ ${ }^{1}$ Department of Natural Resources, Isfahan University of Technology \\ 84156-8311 Isfahan, Iran (phone: +98-313-391-2210; fax: +98-313-391-2862) \\ ${ }^{2}$ Faculty of Agriculture, Department of Agronomy and Plant Breeding, University of Kurdistan \\ 66177-15175 Sanandaj, Iran (phone: +98-873-366-4600; fax: +98-873-362-4240) \\ ${ }^{3}$ College of Agriculture, Department of Agronomy and Plant Breeding, Isfahan University of \\ Technology, 84156-8311 Isfahan, Iran (phone: +98-313-391-34307; fax: +98-313-391-3458) \\ *Corresponding author \\ e-mail: m.gurgin@na.iut.ac.ir; phone:+98-918-371-4478; fax: +98-313-391-2840 \\ **Coordinator \\ (Received 13 ${ }^{\text {th }}$ Jul 2018; accepted 28 ${ }^{\text {th }}$ Sep 2018)
}

\begin{abstract}
Cardinal temperatures and thermal time are valuable information for scheduling year-round production of seed-propagated species. In this study, thermal germination behavior of three species of the family Fabaceae, Onobrychis subnitens Bornm., Onobrychis scrobiculata Boiss. and Vicia variabilis Grossh., from Kurdistan Province, Iran were quantified. Seeds of these species were germinated at temperatures of 5$35^{\circ} \mathrm{C}$. Three nonlinear regression models (segmented, beta, and dent-like) were used to estimate cardinal temperatures. After examining O.subnitens, findings showed that the segmented model is the best model for predicting cardinal temperatures. The base, optimum, and maximum temperatures were $1.23,17.22$ and $41.10^{\circ} \mathrm{C}$, respectively. The thermal time required for $50 \%$ germination was 21.29 degree-days. For O.scrobiculata, segmented and dent-like models were equal. The base, optimum and maximum temperatures of seed germination were $5.5,18.8-19.76$ and $38.14^{\circ} \mathrm{C}$, respectively. The thermal time required for $50 \%$ germination was 25.87 degree-days. For V.variabilis, there was no difference between the segmented and dentlike models and each one could be chosen. Accordingly, the base, optimum, and maximum temperatures of seed germination were $-1.2,20$ and $35.13^{\circ} \mathrm{C}$, respectively. The thermal time required for $50 \%$ germination was 60.9 degree-days. Based on the germination percentage, germination rate and thermal time requirement, O.subnitens is preferred for use in the arid and semi-arid rangeland improvement project.
\end{abstract}

Keywords: endemic species, Fabaceae, forage production, modeling, rangeland, seed dormancy

\section{Introduction}

Legumes are desirable as human and animal food, and add nitrogen to the soil if effectively nodulated. The high protein and fat content and the low content of cellulose in legumes improve the fodder value and play an important role in soil environments by increasing the nutritive worth of pastures (Abou-El-Enain, 2002). Onobrychis Miller (Sainfoin) which has more than 130 annual and perennial species is found in the Mediterranean region to central Asia. Most species are restricted to northwest Asia, in particular Iran and Anatolia (Yildiz et al., 1999). The productive perennial O.subnitens Bornm has a wide range of habitat types, is endemic to Iran (Jalili and Jamzad, 1999), and widely grown as a pasture legume (Karamian and Ranjbar, 2008). O.scrobiculata Boiss is 
perennial and endemic to Iran (Sanandaji and Mozaffarian, 2010) has a crucial role in soil conservation and considered low-risk in terms of endangered plants in Iran (Jalili and Jamzad, 1999). The genus Vicia L. (Vetch) encompasses approximately 210 species (Hanelt and Mettin, 1989) and its center of diversity is the Mediterranean region (Maxted, 1993). Vicia variabilis Grossh. is a perennial that produces large amounts of hay and has seeds rich in protein, fat, and nitrogenous extractive substances (Mammadova and Gurbanov, 2013). This species is used as a medicinal plant in Iran (Mosaddegh et al., 2012).

Selecting regions with potential for establishment and production requires more information on environmental constraints (Adam et al., 2007). Generally, these three species play significant rules in soil conservation, forage production and rangeland rehabilitation in arid and semi-arid areas (Karamian and Ranjbar, 2008; Mosaddegh et al., 2012). An important constraint in determining the suitability of a crop for production in a region is the range of essential temperatures for germination and seedling growth.

Germination is a complex physiological process affected by different environmental factors such as temperature, light, oxygen, and moisture which has great significance in the ultimate density of the affected crop (Kharkwal et al., 2002). Temperature is a vital regulator of seed germination (Mayer and Marbach, 1981). Three cardinal temperatures (base, optimum, and maximum) indicate the range of temperature over which seeds of a particular species germinate (Bewley and Black, 1994). As the rate of germination increases between the base and optimum temperatures, decreases between optimum and maximum temperature ceases above the maximum and below the base temperatures and an estimation of the cardinal temperatures is necessary (Shafii and Price, 2001). Each species have cardinal temperatures for germination that shows its adaptation to environmental conditions (Alvarado and Bradford, 2002). Thermal-based germination models are widely used to predict germination rates and germination timing of plants. Germination rates usually increase linearly with temperature in the suboptimal range and then decreases linearly (Alvarado and Bradford, 2002). Garcia-Huidobro et al. (1982) developed a thermal time model to calculate the cardinal temperatures and the thermal time constant for both suboptimal and supra-optimal temperatures. Knowing the base temperature and thermal time constants for each species can help predict species distribution transferal under climate change (Midmore, 2015). Increases in mean global temperatures and extremes of temperature are predicted for the future (Kendall, 2012). It is predicted that in Iran, the mean annual temperature will rise by $1.5 \_4.5^{\circ} \mathrm{C}$ (Amiri and Eslamian, 2010). Therefore, one of the direct impacts of climate change is changes in temperature patterns. Plants are unable to move when conditions become unfavorable and so they have developed the ability to readily adapt their growth and developmental processes to changing conditions (Kendall, 2012).

Species vary in their germination and seedling growth responses to temperature (Adam et al., 2007; Biligetu et al., 2011; Windauer et al., 2012; Cardoso and Bianconi, 2013; Javanmard and Eshghizadeh, 2014).

The base temperature and thermal time are important, and can be used to compare germination timing between different species (Zhang et al., 2015). The thermal time model for 10 grass (Wang et al., 2011) and 12 Asteraceae (Liu et al., 2011) species at suboptimal temperatures have been investigated. Hu et al. (2012) compared methods of predicting thermal parameters in four Vicia species. Furthermore, although legume species play a key role in rangeland ecosystems, few studies (Hu et al., 2012; Hu et al., 2015) have evaluated thermal and hydrothermal models of legumes. 
Although there is a rich body of data describing the cardinal temperatures for many agronomic crops and plant species, information on the thermal requirements of many plants is lacking. For most species, germination modeling is an effective approach in determining cardinal temperatures (Parmoona et al., 2015). Knowledge of seed germination responses to environmental factors is necessary for understanding and predicting the ecological adaptation of the species, and for formulating effective strategies for restoration (Fenner and Thompson, 2005).

This study investigates seed germination responses of O.subnitens, O.scrobiculata, and V.variabilis at different temperatures to establish the base, optimum, and maximum temperatures and to determine thermal time requirements which have not been previously studied. This information will be valuable for scheduling year-round production of these seed-propagated species and for providing insights into germination responses in a plant's natural habitat (Cave, 2011).

\section{Materials and methods}

\section{Study area and seed collection}

Mature fruits of O.subnitens and O.scrobiculata were collected from the wild population located between Zakha Olya and Zakha Sofla villages of Divandarre County, Kurdistan Province, Iran at the time of seed dispersal in 2014. Seeds were stored in glass bottles under laboratory conditions ( $\mathrm{RH} 20-45 \% ; 16-22^{\circ} \mathrm{C}$ ) until used in this experiment.

Seeds of V.variabilis were collected from the Saral region of Divandarre County. Seeds were collected as soon as they were ripe and when they had started to disperse naturally in 2014. Seeds were stored dry under laboratory conditions (RH $20-45 \% ; 16-22^{\circ} \mathrm{C}$ ) in a glass bottle until used in this experiment.

The climatic and geographic characteristics of the seed collection area (Saral and Zakha) located in Kurdistan Province, Iran (Figure 1) are shown in Table 1.

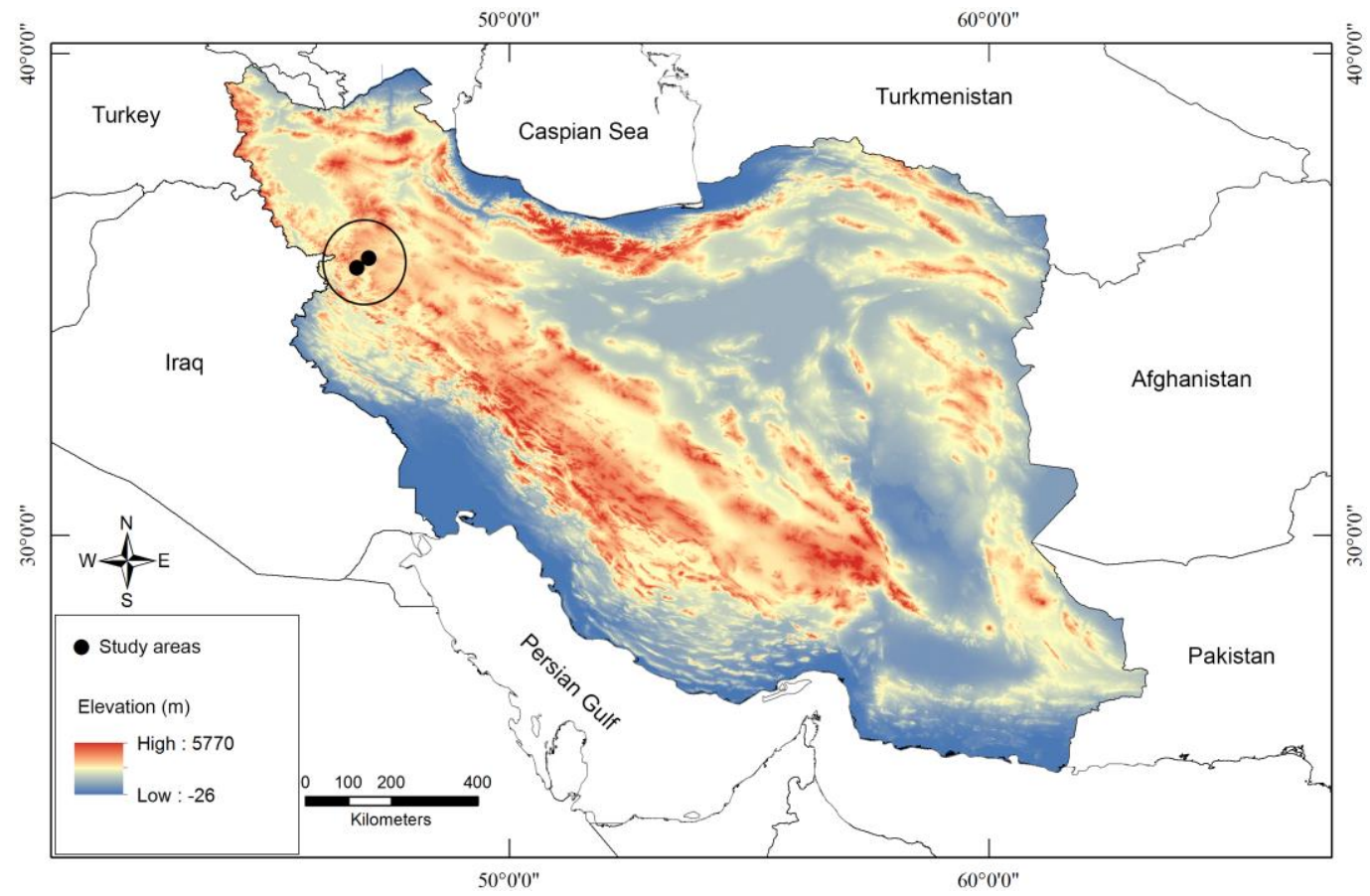

Figure 1. Map of the study area 
Table 1. Environmental and Geographic characteristics of study area

\begin{tabular}{c|c|c|c|c|c}
\hline Location & $\begin{array}{c}\text { Annual average } \\
\text { Temperature }\left({ }^{\circ} \mathbf{C}\right)\end{array}$ & $\begin{array}{c}\text { Rainfall } \\
\text { Annual }(\mathbf{m m})\end{array}$ & $\begin{array}{c}\text { Altitude } \\
(\mathbf{m})\end{array}$ & $\begin{array}{c}\text { Latitude } \\
(\mathbf{N})\end{array}$ & $\begin{array}{c}\text { Longitude } \\
(\mathbf{E})\end{array}$ \\
\hline Saral & 12.27 & 473 & 2170 & $35^{\circ} 30^{\prime}$ & $46^{\circ} 49^{\prime}$ \\
Zakha & 10.91 & 348 & 1786 & $35^{\circ} 45^{\prime}$ & $47^{\circ} 04^{\prime}$ \\
\hline
\end{tabular}

Seed viability, thousand seed weight (TSW) and hard seed (physical dormancy) were determined before experiments commenced. Seed viability and TSW were determined according to the International Seed Testing Rules (ISTA, 2014).

Percentages of hard seed were determined by incubating seeds at $20^{\circ} \mathrm{C}$ and seeds that did not become imbibed within 14 day were considered as hard seed. Since most seeds of the three species had physical dormancy, they were mechanically scarified with different methods. No information existed on the scarification of this species and so various methods were tried (perechiling, using hot water, removing hard shell, using concentrated sulphuric acid (98\%) solution for 3 minutes, 5 minutes, 10 minutes, 15 minutes, and 30 minutes). Finally, methods with the highest germination percentage was chosen: dipping V.variabilis in a concentrated sulphuric acid (98\%) solution for 5 minutes and washing with distilled water, removing the hard shell of O.subnitens fruit and then dipping in concentrated sulphuric acid (98\%) solution for 3 minutes and washing with distilled water, and removing the hard shell of O.scrobiculata fruit.

\section{Germination tests}

After scarification, the seeds were disinfected with sodium hypochlorite for one minute followed by washing with distilled water. Four replicates of the 50 seeds were germinated in $12 \mathrm{~cm}$ sterilized plastic Petri dishes on top of one layer of filter paper and then moistened by adding $5 \mathrm{ml}$ of distilled water. The Petri dishes were enclosed and sealed in polyethylene bags to prevent dehydration. Seeds were incubated in darkness at constant temperatures from $5-35^{\circ} \mathrm{C}$ (at intervals of $5^{\circ} \mathrm{C}$ ) (Lonati et al., 2009; McCartan et al., 2015; Hu, 2015; Zhang et al., 2015). Seeds with a radicle longer than $2 \mathrm{~mm}$ were considered germinated. Germination counts were made daily for 15 days until the cumulative germination became stable over three consecutive days and this lasted 15 days.

\section{Statistical analysis}

The rate of germination is a more sensitive index than the germination percentage in response to temperature and moisture potential (Steinmaus et al., 2000; Khalili et al., 2013). Therefore, under normal conditions, the use of the germination rate index for different plant species to fit regression models show better results in determining cardinal temperatures (Sadrabadi Haghighi and Sazevari, 2011). Hence, the germination rate was investigated to determine cardinal temperatures. For modeling purposes, germination percentage (GP) and germination rate (R50) were calculated by using the Germin program (Soltani and Maddah-Yazdi, 2010). Germin program calculates the percentage of germination using Eq.1 (Belcher and Miller, 1974):

$$
\mathrm{Gp}=\sum\left(\mathrm{ni}^{*} 100 / \mathrm{N}\right)
$$


where $\mathrm{Gp}$ is percentage of germination, ni is number of germinated seed/day and $\mathrm{N}$ is number of days that seeds were monitored.

Rate of germination was determined by Eq.2 (Hartman et al., 1990):

$$
\mathrm{GR}=\Sigma \mathrm{ni} / \mathrm{N}
$$

where $\mathrm{Gp}$ is percentage of germination, ni is number of germinated seed/day and $\mathrm{N}$ is number of days that seeds were monitored.

For each species, a completely randomized experimental design was used with four replications. A one-way ANOVA was used to test differences in GP and R50 of 5, 10, $15,20,25,30$ and $35^{\circ} \mathrm{C}$. Mean results were also compared by Duncan's test (performed at the $5 \%$ significance level).

There are many thermal functions to show the response of germination to temperature. Three more efficient temperature functions (beta $(E q .3)$, segmented (Eq.4) and dent-like (Eq.5)) were used (Soltani et al., 2006; Soltani et al., 2008).

Beta function with ( $\beta$ ) Symbol:

$$
\begin{array}{ll}
\mathrm{f}(\mathrm{T})=\left\{\left[\left(\frac{T-T_{b}}{T_{o}-T_{b}}\right)\left(\frac{T_{c}-T}{T_{c}-T_{o}}\right)\right]^{\left(T_{c}-T_{o}\right) /\left(T_{o}-T_{b}\right)}\right\}^{\alpha} & \text { if } \mathrm{T}>\mathrm{T}_{\mathrm{b}} \text { and } \mathrm{T}<\mathrm{T}_{\mathrm{c}} \\
\mathrm{f}(\mathrm{T})=0 & \text { if } \mathrm{T} \leq \mathrm{T}_{\mathrm{b}} \text { or } \mathrm{T} \geq \mathrm{T}_{\mathrm{c}}
\end{array}
$$

Segmented function:

$$
\begin{array}{ll}
\mathrm{f}(\mathrm{T})=\left(\mathrm{T}-\mathrm{T}_{\mathrm{b}}\right) /\left(\mathrm{T}_{\mathrm{o}}-\mathrm{T}_{\mathrm{b}}\right) & \text { if } \mathrm{T}_{\mathrm{b}}<\mathrm{T} \leq \mathrm{T}_{\mathrm{o}} \\
\mathrm{f}(\mathrm{T})=\left(\mathrm{T}_{\mathrm{c}}-\mathrm{T}\right) /\left(\mathrm{T}_{\mathrm{c}}-\mathrm{T}_{\mathrm{o}}\right) & \text { if } \mathrm{T}_{\mathrm{o}}<\mathrm{T}<\mathrm{T}_{\mathrm{c}} \\
\mathrm{f}(\mathrm{T})=0 & \text { if } \mathrm{T} \leq \mathrm{T}_{\mathrm{b}} \text { or } \mathrm{T} \geq \mathrm{T}_{\mathrm{c}}
\end{array}
$$

Dent-like:

$$
\begin{array}{ll}
\mathrm{f}(\mathrm{T})=\left(\mathrm{T}-\mathrm{T}_{\mathrm{b}}\right) /\left(\mathrm{T}_{\mathrm{o} 1}-\mathrm{T}_{\mathrm{b}}\right) & \text { if } \mathrm{T}_{\mathrm{b}}<\mathrm{T}<\mathrm{T}_{\mathrm{o} 1} \\
\mathrm{f}(\mathrm{T})=\left(\mathrm{T}_{\mathrm{c}}-\mathrm{T}\right) /\left(\mathrm{T}_{\mathrm{c}}-\mathrm{T}_{\mathrm{o} 2}\right) & \text { if } \mathrm{T}_{\mathrm{o} 2}<\mathrm{T}<\mathrm{T}_{\mathrm{c}} \\
\mathrm{f}(\mathrm{T})=1 & \text { if } \mathrm{T}_{\mathrm{o} 1}<\mathrm{T}<\mathrm{T}_{\mathrm{o} 2} \\
\mathrm{f}(\mathrm{T})=0 & \text { if } \mathrm{T} \leq \mathrm{T}_{\mathrm{b}} \text { or } \mathrm{T} \geq \mathrm{T}_{\mathrm{c}}
\end{array}
$$

where $T, T_{b}, T_{o}$, and $T_{c}$ are mean, base, optimum, and maximum temperature, respectively, $\mathrm{To}_{1}$ is the lower optimum temperature (for dent-like function), $\mathrm{To}_{2}$ is the upper optimum temperature (for dent-like function) based on degree centigrade. $\alpha$ is the shape parameter of the beta function. To determine these parameters, PROC NLIN in SAS was used. The coefficient of determination $\left(\mathrm{R}^{2}\right)$, the coefficient of variation $(\mathrm{CV})$, and lower deviations of the intercept from 0 and of the slope from 1 corresponding to the increased reliability (RMSE) were used to choose the best model.

To compare the model for estimating cardinal temperature, the Akaike Information Criterion (AIC) was used (Eq. 6) (Burnham and Anderson, 2002).

$$
\mathrm{AIC}=\mathrm{n} * \operatorname{Ln}(\text { ss model } / \mathrm{n})+2 * \mathrm{k}
$$

where $\mathrm{n}$ is the number of data points (observations), $\mathrm{Ln}$ is the natural logarithm, RSS is the residual sums of squares and $\mathrm{K}$ is the number of parameters in the model.

Thermal time $\left(\theta,{ }^{\circ} \mathrm{C}\right.$ day) estimates for each species was calculated by using Eq. 7 for suboptimal and Eq. 8 for supra-optimal temperatures (Bradford, 2002): 


$$
\begin{gathered}
\text { TTsub }=\left(T-T_{b}\right) \operatorname{tg} \\
\text { TTsupra }=\left(T_{c}-T\right) \operatorname{tg}
\end{gathered}
$$

where $T$ is the germination temperature, $T_{b}$ and $T_{c}$ are base and maximum temperature, and $\operatorname{tg}$ is the needed time to reach $50 \%$ of the germination.

\section{Results}

\section{Effect of temperature on germination percentage}

Temperature had a significant effect on both the percentage and rate of germination for all species $(\mathrm{p}=0)$. Highest germination of O.scrobiculata occurred between $15-20^{\circ} \mathrm{C}$ (more than 93\%); the lowest germination percentage was at $5^{\circ} \mathrm{C}$ (no seed germinated). The highest germination for O.subnitense occurred at the temperature range of $10-20^{\circ} \mathrm{C}$ (more than 90\%) and the lowest germination percentages at $5^{\circ} \mathrm{C}$ and $35^{\circ} \mathrm{C}$. For Vicia variabilis, the optimum germination temperature was between $10^{\circ} \mathrm{Cand} 20^{\circ} \mathrm{C}$ (more than $88 \%$ ); but no seed germinated at $35^{\circ} \mathrm{C}$ (Figure 2).

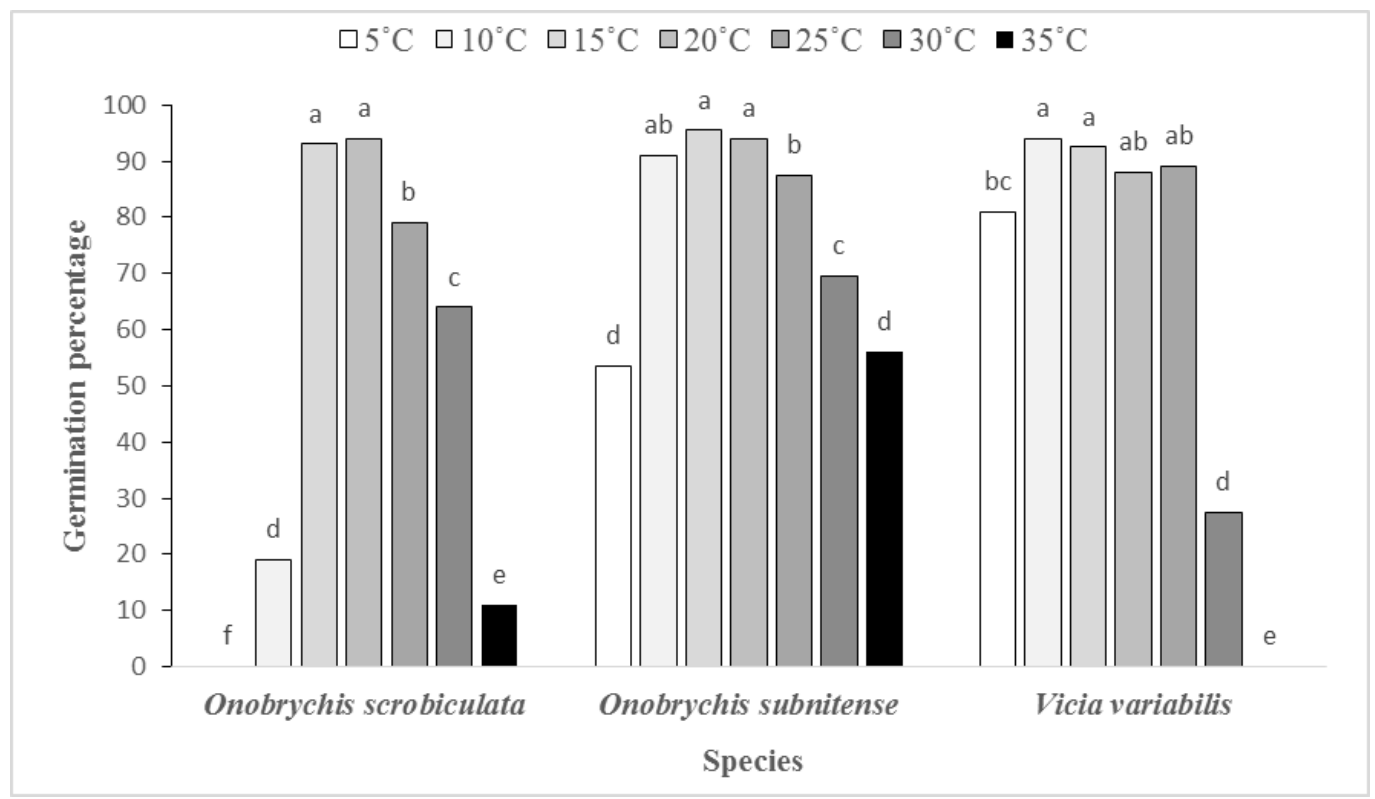

Figure 2. Germination percentage for the three species seeds affected by different temperature (values followed by different letters are significantly different $(P<0.05)$

\section{Effect of temperature on germination rate}

The fastest germination rate for O.scrobiculata was observed at $20^{\circ} \mathrm{C}(10 \mathrm{seed} /$ day $)$, and the slowest rates at $5^{\circ} \mathrm{C}, 35^{\circ} \mathrm{C}$, and $10^{\circ} \mathrm{C}$. The maximum germination rate of O.subnitense was at $15^{\circ} \mathrm{C}$ and $20^{\circ} \mathrm{C}$, and the minimum at both $5^{\circ} \mathrm{C}$ and $35^{\circ} \mathrm{C}$. Vicia variabilis germinated fastest at $20^{\circ} \mathrm{C}$, but at $35^{\circ} \mathrm{C}$ was 0 (Figure 3 ). 


$$
-7611 \text { - }
$$

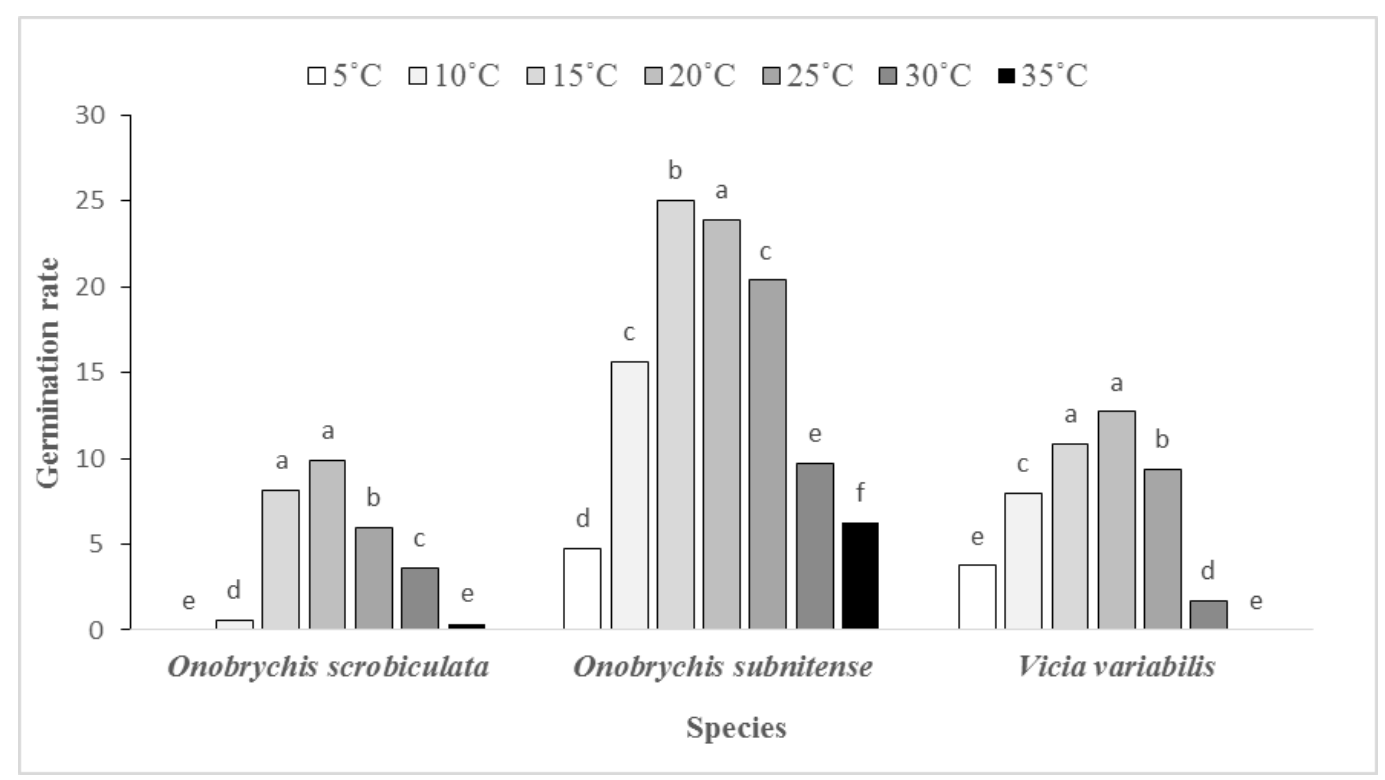

Figure 3. Germination rate for three species seed affected by different temperature (values followed by different letters are significantly different $(P<0.05)$

\section{Use of models to explain germination}

Cardinal temperatures and maximum germination rate of the studied species based on beta, segmented and dent-like models are shown in Table 2. The beta and dent-like models were not useful for calculating the cardinal temperature for O.subnitens (Pvalues> 0.05 in Table 2), whereas the segmented model was useful. Based on the segmented model, the cardinal temperatures for the base, optimum and maximum were $1.33^{\circ} \mathrm{C}, 17.15^{\circ} \mathrm{C}$ and $41.83^{\circ} \mathrm{C}$, respectively.

The beta model could not be used to determine the cardinal temperatures for O.scrobiculata (P-values>0.05). The other indices $\left(\mathrm{R}^{2}, \mathrm{RMSE}, \mathrm{CV}\right.$ and $\mathrm{AIC}$ ) for the other models (segmented and dent-like) were similar, and both models can be used to calculate cardinal temperatures. The minimum germination temperature was $5.5^{\circ} \mathrm{C}$, the upper limit of the optimum temperature was $18.87^{\circ} \mathrm{C}$, the lower limit of the optimum temperature was $19.69^{\circ} \mathrm{C}$ (optimum temperature with the segmented model was $19.22^{\circ} \mathrm{C}$ ) and the maximum germination temperature was $38.06^{\circ} \mathrm{C}$.

All three models for V.variabilis were acceptable (P-values $<0.05)$. However, the beta model is not a good model $\left(\mathrm{R}^{2}\right.$ beta model $<\mathrm{R}^{2}$ dent-like and $\mathrm{R}^{2}$ segmented model). In the dent-like and segmented models, $\mathrm{R}^{2}$, RMSE, and CV were similar, but the AIC index of the dent-like model was less than the segmented model. Hence, the dent-like model appears to be the most suitable model. In this model, the base temperature was $1.35^{\circ} \mathrm{C}$, the lower limit of the optimum temperature was $19.44^{\circ} \mathrm{C}$, the upper limit of the optimum temperature was $20.9^{\circ} \mathrm{C}$, and maximum temperature was $38.06^{\circ} \mathrm{C}$.

The thermal time model is described well and the relationship between germination rate and temperature $\left(\mathrm{R}^{2}>0.9\right)$ is illustrated in Tables 3 and 4.

V.variabilis has the highest and O.subnitens has lowest thermal time constant coefficient in sub-optimal temperatures.

In supra sub-optimal temperatures V.variabilis has the highest and O.subnitens has the lowest thermal time constant. 
Table 2. Cardinal temperatures, maximum germination rate, significant level, $R^{2}, R M S E, C V$ and AIC of segmented, Beta and Dent like model in three species

\begin{tabular}{|c|c|c|c|c|c|c|c|c|c|c|}
\hline \multirow{2}{*}{ species } & \multirow{2}{*}{ model } & \multicolumn{3}{|c|}{ cardinal temperatures } & \multirow{2}{*}{$r \max$} & \multirow{2}{*}{ P-value } & \multirow{2}{*}{$\mathrm{R}^{2}$} & \multirow{2}{*}{ RMSE } & \multirow{2}{*}{$\mathrm{CV}$} & \multirow{2}{*}{ AIC } \\
\hline & & base & optimum & maximum & & & & & & \\
\hline \multirow{3}{*}{ O. subnitense } & Beta & $1 * 10-8 \pm 1$ & $20 \pm 8.6$ & $35 \pm 7.5$ & 0.022 & 0.54 & 0.95 & 0.0019 & 18.2 & -254.51 \\
\hline & Segmented & $1.2 \pm 1.6$ & $17.2 \pm 1.1$ & $41.1 \pm 2.3$ & 0.031 & 0.01 & 0.96 & 0.0018 & 10.2 & -303.88 \\
\hline & Dent like & $1.3 \pm 1.6$ & $\begin{array}{l}15.0 \pm 1.6 \\
212 \pm 2.8\end{array}$ & $41.05 \pm 2.8$ & 0.027 & 0.052 & 0.97 & 0.0014 & 8.23 & -302.72 \\
\hline \multirow{3}{*}{ O. scrobiculata } & Beta & $1 * 10-8 \pm 2$ & $20 \pm 2.2$ & $35 \pm 19.8$ & 0.022 & 0.2 & 0.9 & 0.0029 & 28 & -272.8 \\
\hline & Segmented & $5.5 \pm 0.9$ & $19.2 \pm 1.0$ & $38.1 \pm 1.5$ & 0.023 & 0.006 & 0.97 & 0.0013 & 12 & -305.59 \\
\hline & Dent like & $5.5 \pm 0.9$ & $\begin{array}{l}18.8 \pm 1.46 \\
197 \pm 12\end{array}$ & $38.1 \pm 1.5$ & 0.022 & 0.006 & 0.97 & 0.0013 & 12 & -303.59 \\
\hline \multirow{3}{*}{ V.variabilis } & Beta & $-2 \pm .01$ & $18.9 \pm 1.3$ & $35.4 \pm 4.7$ & 0.012 & 0.0047 & 0.94 & 0.0012 & 16 & -296.8 \\
\hline & Segmented & $-1.2 \pm 1.6$ & $20 \pm 0.6$ & $35.1 \pm 0.5$ & 0.13 & 0.0014 & 0.99 & 0.0004 & 6.5 & -335.63 \\
\hline & Dent like & $-1.4 \pm 1.6$ & $\begin{array}{l}21.0 \pm 1.5 \\
19.6 \pm 0.5\end{array}$ & $35.1 \pm 0.5$ & 0.14 & 0.0013 & 0.99 & 0.0004 & 6.45 & -333.63 \\
\hline
\end{tabular}

Table 3. The thermal time constant coefficient $(\theta T))$ for temperatures lower than the optimal temperature

\begin{tabular}{c|c|c|c}
\hline species & $\begin{array}{c}\theta_{\mathrm{T}} \pm \mathrm{SE} \\
\left({ }^{\circ} \mathrm{C} / \mathrm{day}\right)\end{array}$ & $\mathrm{p}$ & $\mathrm{R}$ \\
\hline O. subnitense & $21.3 \pm 1.2$ & 0.3 & 0.99 \\
O.scrobiculata & $25.8 \pm 2.4$ & 0.008 & 0.0008 \\
V.variabilis & $59.4 \pm 3.2$ & 0.002 & 0.0016 \\
\hline
\end{tabular}

Table 4. The thermal time constant coefficient $(\theta T))$ for temperatures greater than the optimal

\begin{tabular}{|c|c|c|c|c|}
\hline species & $\begin{array}{c}\theta_{\mathrm{T}} \pm \mathrm{SE} \\
\left({ }^{\circ} \mathrm{C} / \mathrm{day}\right)\end{array}$ & $\mathrm{p}$ & $\mathrm{R}^{2}$ & RMSE \\
\hline $\begin{array}{c}\text { O.subnitense } \\
\text { O.scrobiculata } \\
\text { V.variabilis }\end{array}$ & $\begin{array}{c}31.7 \pm 6.1 \\
33.9 \pm 3.99 \\
44.4 \pm 2.9 \\
\end{array}$ & $\begin{array}{c}0.03 \\
0.01 \\
0.004 \\
\end{array}$ & $\begin{array}{l}0.92 \\
0.97 \\
0.99 \\
\end{array}$ & $\begin{array}{l}0.0028 \\
0.0015 \\
0.0007 \\
\end{array}$ \\
\hline
\end{tabular}

APPLIED ECOLOGY AND ENVIRONMENTAL RESEARCH 16(6):7605-7617.

http://www.aloki.hu • ISSN 15891623 (Print) • ISSN 17850037 (Online)

DOI: http://dx.doi.org/10.15666/aeer/1606_76057617

(c) 2018, ALÖKI Kft., Budapest, Hungary 


\section{Discussion}

Seed germination performances studied under laboratory conditions are critical to understand species distribution (Kissmann and Habermann, 2013). O.subnitense had the highest germination percentage and germination rate (6.4 seeds/hour) in this study. The base temperatures for V.variabilis was below zero. Base temperatures can be below $0^{\circ} \mathrm{C}$ in rangeland species (Hardegree and Van Vactor, 1999; Trudgill et al., 2000). Although $V$. variabilis has tolerance to negative temperatures, O.subnitense has a higher germination rate and germination percentage which means it can resist cold weather better. By increasing temperatures up to an optimum level, the rate of germination was increased and declined thereafter (Alvarado and Bradford, 2002). Hu (2015) has confirmed this result for approximately eight different plants of the Fabaceae family. The germination rate has a positive linear relationship between sub-optimal temperatures, and a negative linear relationship between supra-optimal temperatures. Previous studies have presented similar results (Garcia-Huidobro et al., 1982; Orru et al., 2012; Ordo nez-Salanueva, 2015).

A fast germination can increase the probability of timely exit radicle from seed and use of soil moisture as well as better seedling placement. As the temperature rises above the optimum temperature, the germination rate of the seeds decreases and at maximum temperature, the rate and germination percentage become zero (Evers, 1991). The germination process involves a series of biochemical interactions that are more dependent on temperature and water. Temperature affects active water absorption by seeds in a moist environment. Reduced enzyme activity at low temperatures and disrupted enzyme activity at high temperatures (desaturated three-dimensional building enzymes) are the main causes of reduced germination percentage at high and low temperatures (Maiti and Wesche-Ebeling, 2001). Copland and McDonald (1995) considered the change in essential protein germination the reason for stopping germination at maximum temperatures. Reducing the rate of germination by decreasing temperature is also partly related to the slow reduction of seed imbibition rates (Bewley and Black, 1994). Hardegree (2006) indicated that high temperatures can reduce germination rate and cause seed destruction. Species that have a higher germination rate and a higher germination percentage can resist cold weather better (Pessarakli, 1999).

A recent literature review showed that thermal time was negatively correlated with base temperature; species with low base temperatures required more thermal time to reach 50\% germination and vice versa (Durr et al., 2015; McCartan et al., 2015; Midmore, 2015). The results of this study indicate that amongst the three species studied, Vicia variabilis with a lower base temperature had a higher amount of thermal time which is in line with the findings of Durra et al. (2015) and McCartan et al. (2015). However, Onobrychis scrobiculata with the highest base temperature did not have the lowest thermal time. Cave (2011) showed Brunonia australis has a lower base temperature and thermal time requirement, whereas Calandrinia sp. has a higher base temperature and greater thermal time requirement.

\section{Conclusion}

According to the results of the present study, it can be concluded that with cardinal temperature, O.subnitense, O.scrobiculata, and V.variabilis have adapted to their local climatic conditions (Table 1 and Table 2). As a result, the best species for use in 
rangeland rehabilitation projects is one which can tolerate higher temperatures. O.subnitense has the highest Tc (Table 2) and it can resist hot weather better. In general, species that have higher germination rates and higher germination percentages can resist cold weather better. It is recommended to apply O.subnitense in rangeland rehabilitation projects because of the high germination percentages and high germination rates in a vast range of temperatures.

Acknowledgements. The authors would like to thank the staff of the Plant Physiology Laboratory of the University of Kurdistan, in particular Ms. Peghah Shahidi, for their help in laboratory analysis. Special thanks to Dr.Parviz Karami, Dr. Farshid Ghaderifar, Dr. Nabi Khalili Aghdam and Dr.Azad Rasteghar for their technical assistance.

Conflict of interests. The authors declare no conflict of interests.

\section{REFERENCES}

[1] Abou-el-Enain, M. M. (2002): Chromosomal criteria and their phylogenetic implications in the genus Onobrychis Miller. Sect. Lophobrychis (Leguminosae), with special reference to Egyptian species. - Botanical Journal of the Linnean Society 139: 409-414. doi: 10.1046/j.1095-8339.2002.00075.x.

[2] Adam, N. R., Dierig, D. A., Coffelt, T. A., Wintermeyer, M. J., Mackey, B. E., Wall, G. W. (2007): Cardinal temperatures for germination and early growth of two Lesquerella species. - Industrial Crops and Products 25: 24-33. doi: 10.1016/j.indcrop.2006.06.001

[3] Alvarado, V., Bradford, K. J. (2002): A hydrothermal time model explains the cardinal temperatures for seed germination. - Plant Cell Environmental 25: 1061-1069. doi: 3040.2002.00894.x.

[4] Belcher, E. W., Miller, L. (1974): Influence of substrate moisture level on the germination of sweet gum and sand pine seed. - Proceeding of the Association of Official Seed Analysis 64: 109-114.

[5] Bewley, J. D., Black, M. (1994): Seeds: Physiology of Development and Germination. Springer: New York.

[6] Biligetu, B., Schellenberg, M. P., McLeod, J. G. (2011): The effect of temperature and water potential on seed germination of poly-cross side-oats grama (Bouteloua curtipendula (Michx.) Torr.) Population of Canadian prairie. - Seed Science and Technology 39: 74-81.

[7] Bradford, K. J. (2002): Applications of hydrothermal time to quantifying and modeling seed germination and dormancy. - Weed Science 50: 248-260. doi: 10.1614/00431745(2002)050[0248:AOHTTQ]2.0.CO;2.

[8] Burnham, K. P., Anderson, D. R. (2002): Model Selection and Multimodal Inference: A Practical Information-Theoretic Approach. - Springer, New York, USA. doi: $10.1177 / 0049124104268644$.

[9] Cardoso, V. J. M., Bianconi, A. (2013): Hydrotime model can describe the response of common bean (Phaseolus vulgaris L.) seeds to temperature and reduced water potential. Acta Scientiarum. Biological Sciences Maringá 35(2): 255-261. doi:10.4025/actascibiolsci.v35i2.15393.

[10] Cave, R. L. (2011): Cardinal Temperatures and Thermal Time for Seed Germination of Brunonia australis (Goodeniaceae) and Calandrinia sp. (Portulacaceae). - Hort. Science 46(5): 753-758.

[11] Copeland, L. O., McDonald, M. B. (1995): Principles of Seed Science and Technology. Pub. Chapman \& Hall: USA. 
[12] Durr, C., Dickie, J. B., Yang, X-Y, Pritchard, H. W. (2015): Ranges of critical temperature and water potential values for the germination of species worldwide: contribution to a seed trait database. - Agricultural and Forest Meteorology 200: 222232. doi:org/10.1016/j.agrformet.2014.09.024.

[13] Evers, G. W. (1991): Germination response of subterranean, berseem and rose clovers to alternating temperatures. $\quad-\quad$ Agronomy 83: 1000-1004. doi:10.2134/agronj1991.00021962008300060015x.

[14] Fenner, M., Thompson, K. (2005): The Ecology of Seeds. - Cambridge University Press, Cambridge, UK.

[15] Garcia-Huidobro, J., Monteith, J. L., Squier, G. R. (1982): Time, temperature and germination of Pearl Millet (Pennisetum typhoides, S and H): I. Constant Temperature. Journal of Experimental Botany 33: 288-296. doi:org/10.1093/jxb/33.2.288.

[16] Hanelt, P., Mettin, D. (1989): Biosystematics of the genus Vicia L. (Leguminosae). Annual Review of Ecology, Evolution and Systematics 20: 199-223. doi:10.1146/annurev.es.20.110189.001215.

[17] Hardegree, S. (2006): Predicting germination response to temperature: Cardinal temperature models and subpopulation-specific regression. - Annals of Botany 97: 11151125. doi:10.1093/aob/mcl071.

[18] Hardegree, S., Van Vactor, S. S. (1999): Predicting germination response of four coolseason range grasses to field variable temperature regimes. - Journal of Experimental Botany 41: 209-217. doi: 10.1016/S0098-8472(99)00004-0.

[19] Hartman, H., Kester, D., Davis, F. (1990): Plant propagation, principle and practices. Prentice Hall Imitational Edition. 647p.

[20] Hu, X. W., Wang, J., Wang, Y. R. (2012): Thermal time model analysis for seed germination of four Vicia species. - Chinese Journal of Plant Ecology 36: 841-848.

[21] Hu, X. W., Fan, Y., Baskin, C. C., Baskin, J. M., Wang, Y. R. (2015): Comparison of the effects of temperature and water potential on seed germination of Fabaceae species from desert and subalpine grassland. - American Journal of botany 102(5): 649-660. https://doi:10.3732/ajb.1400507.

[22] ISTA. (2014): International rules for seed testing. - International Seed Testing Association (ISTA). Edition 2014.

[23] Jalili, A., Jamzad, Z. (1999): Red data book of Iran: a preliminary survey of endemic, rare and endangered plant species in Iran. - Research Institute of Forests and Rangelands (RIFR), Tehran, Iran. 748p.

[24] Javanmard, H. R., Eshghizadeh, H. R. (2014): Germination Properties and Cardinal Temperatures of Blue Panic Grass (Panicum antidotale). - Seed Technology 36(1): 1-7.

[25] Karamian, R., Ranjbar, M. (2008): Plant regeneration from Onobrychis subnitens BORNM hypocotyl explant via somatic embryogenesis and organogenesis. - Acta Biologica Cracoviensia Series Botanica 50(2): 13-18.

[26] Kendall, S. (2012): Temperature regulation of seed dormancy and germination in Arabidopsis thaliana. PhD Thesis. - University of York Department of Biology.

[27] Khalili, N., Soltani, A., Zeinali, E., Ghaderifar, F. (2013): Evaluation of nonlinear regression models to quantify barley germination rate response to temperature and water potential. - Electronic Journal of Crop Production 7(4): 23-40 (in Persian).

[28] Kharkwal, A. C., Prakash, O. M., Bhattacharya, A., Nagar, P. K., Ahuja, P. S. (2002): Method for inducing improved seed germination in Podophyllum hexandrum Royle. United States Patent 6: 449-899.

[29] Kissmann, C., Habermann, G. (2013): Seed germination performances of Styrax species help understand their distribution in Cerrado areas in Brazil. - Bragantia Campinas 72(3): 199-207.

[30] Liu, W., Liu, K., Zhang, C. H., Du, G. Z. (2011): Effect of accumulated temperature on seed germination_A case study of 12 Compositae species on the eastern Qinghai-Tibet Plateau of China. - Chinese Journal of Plant Ecology 35: 751-758. 
[31] Lonati, M., Moot, D. J., Aceto, P., Cavallero, A., Lucas, R. J. (2009): Thermal time requirements for germination, emergence and seedling development of adventive legume and grass species. - New Zealand Journal of Agricultural Research 52: 17-29. doi.org/10.1080/00288230909510485.

[32] Maiti, R., Wesche-Ebeling, P. (2001): Advance in Chickpea Science. - Science publishers, Inc.

[33] Mammadova, Z., Gurbanov, E. (2013): Phytochemical Composition of Some Vicia L. Genus Species. - International Caucasian forestry symposium: 1068-1071.

[34] Maxted, N. (1993): A phonetic investigation of Vicia L. subgenus Vicia (Leguminosae, Vicieae). - Botanical Journal of the Linnaean Society 111: 155-182. doi: 10.1111/j.10958339.1993.tb01897.x.

[35] Mayer, A. M., Marbach, I. (1981): Biochemistry of the transition from resting to germinating state in seeds. - Progress in Photochemistry 7: 95-136.

[36] McCartan, S. A., Jinks, R. L., Barsoum, N. (2015): Using thermal time models to predict the impact of assisted migration on the synchronization of germination and shoot emergence of oak (Quercus robur L.). - Annals of Forest Science 72: 479-487.

[37] Midmore, E. K., McCartan, S. A., Jinks, R. L., Cahalan, C. M. (2015): Using thermal time models to predict germination of five provenances of silver birch (Betula pendula Roth) in southern England. - Silva Fenica 49(2): 1-12. doi. 10.14214/sf.1266.

[38] Mosaddegh, M., Hamzeloo Moghadam, M., Naghibi, F., Mohebby, S., Pirani, A., Eslami, B. (2012): Vicia variabilis a Nutritive Feed for Domesticated Animals: A Survey about Cytotoxic and Antioxidant Activity. - Iranian Journal of Applied Animal Science 2(3): 283-286. doi: 10.1007/s13595-014-0454-5.

[39] Ordo nez-Salanueva, C. A., Seal, C. E., Pritchard, H. W., Orozco-Segovia, A., CanalesMartínez, M., Flores-Ortiz, C. M. (2015): Cardinal temperatures and thermal time in Polaskia Backeb (Cactaceae) species: Effect of projected soil temperature increase and nurse interaction on germination timing. - Journal of Arid Environments 115: 73-80. doi: 10.1016/j.jaridenv.2015.01.006.

[40] Orru, M., Mattana, E., Pritchard, H. W., Bacchetta, G. (2012): Thermal thresholds as predictors of seed dormancy release and germination timing: altitude-related risks from climate warming for the wild grapevine Vitis vinifera subsp. sylvestris. - Annals of Botany 110: 1651-1660. doi: 10.1093/2Faob/2Fmcs218.

[41] Parmoona, G., Moosavi, S. A., Akbari, H., Ebadi, A. (2015): Quantifying cardinal temperatures and thermal time required for germination of Silybum marianum seed. The Crop Journal 3: 145-151. doi: 10.1016/j.cj.2014.11.003.

[42] Pessarakli, M. (1999): Handbook of Plant and Crop Stress, 2nd Edition, Revised and Expanded - Marcel Dekker, Inc., New York.

[43] Sadrabadi Haghighi, R., Sazevari, G. (2011): Evaluation of effect on Alhaji pseudlhaji germination response to salinity and temperature. - World Applied Sciences Journal 13 (1): $157-164$.

[44] Sanandaji, S., Mozaffarian, V. (2010): Studies of Flora in Saral area: Kurdistan-Iran. Taxonomy and Biosystematics 2(3-4):59-84. (in Persian).

[45] Shafii, B., Price, W. J. (2001): Estimation of cardinal temperatures in germination data analysis. - Journal of Agricultural, Biological, and Environmental Statistics 6: 356-366. https://doi: 10.1198/108571101317096569.

[46] Soltani, A., Robertson, M. J., Torabi, B, Yousefi-Daz, M., Sarparast, R. (2006): Modeling seedling emergence in chickpea as influenced by temperature and sowing depth. Agricultural and Forest Meteorology 8: 156-167.

[47] Soltani, E., Galeshi, S., Kamkar, B., Akramghaderi, F. (2008): Modeling Seed Aging Effects on the Response of Germination to Temperature in Wheat. - Seed Science biotechnology 2: 32-36.

[48] Soltani, A., Maddah, V. (2010): Simple, applied programs for education and research in agronomy. - Niak Press, Tehran (in Persian). 
[49] Steinmaus, S. J., Prather, T. S., Holt, J. S. (2000): Estimation of base temperature for nine weeds species. - Journal of Experimental Botany 51: 275-286. doi: 10.1093/jexbot/51.343.275.

[50] Trudgill, D. L., Squire, G. R., Thompson, K. (2000): A thermal time basis for comparing the germination requirements of some British herbaceous plants. - The New Phytologist 145: 107-114.

[51] Wang, M. Y., Liu, W., Liu, K., Bu, H. Y. (2011): The base temperature and the thermal time requirement for seed germination of 10 grass species on the eastern Qinghai-Tibet Plateau. - Pratacultural Science 28: 983-987.

[52] Windauer, L., Martinez, J., Rapoport, D., Wassner, D., Benech-Arnold, R. (2012): Germination responses to temperature and water potential in Jatropha curcas seeds: a hydrotime model explains the difference between dormancy expression and dormancy induction at different incubation temperatures. - Annals of Botany 109: 265-273. doi:org/10.1093/aob/mcr242.

[53] Yildiz, B., Ciplak, B., Aktoklu, E. (1999): Fruit morphology of sections of the genus Onobrychis Miller (Fabaceae) and its phylogenetic implications. - Israel Journal Plant Science 47: 269-282. doi: 10.1080/07929978.1999.10676784

[54] Zhang, H., Tian, Y., Zhou, D. (2015): A Modified Thermal Time Model Quantifying Germination Response to Temperature for C3 and C4 Species in Temperate Grassland. Agriculture 5: 412-426. doi:10.3390/agriculture5030412 